\title{
DEEP FERTILIZER PLACEMENT IMPROVES RICE GROWTH AND YIELD IN ZERO TILLAGE
}

\author{
Du, B. ${ }^{1,2 \#}-$ LUO, H. W. ${ }^{1,2 \#}-$ HE, L. X. ${ }^{1,2 \#}-$ ZHENG, A. X. ${ }^{1}-$ CHEN, Y. L. ${ }^{1}-$ ZHANG, T. T. ${ }^{1,2}-$ \\ WANG, Z. M. ${ }^{3}-\mathrm{HU}, \mathrm{L}^{3}-\mathrm{TANG}, \mathrm{X} . \mathrm{R}^{1,2^{*}}$ \\ ${ }^{I}$ Department of Crop Science and Technology, College of Agriculture, South China Agricultural \\ University, 510642 Guangzhou, PR China \\ ${ }^{2}$ Scientific Observing and Experimental Station of Crop Cultivation in South China, Ministry of \\ Agriculture, 510642 Guangzhou, PR China \\ ${ }^{3}$ Key Laboratory of Key Technology for South Agricultural Machine and Equipment, Ministry of \\ Education, 510642 Guangzhou, PR China \\ ${ }^{\#}$ These authors have contributed equally to this work. \\ *Corresponding author \\ e-mail:tangxr@scau.edu.cn; phone/fax: +20-8528-0204-618 \\ (Received 24 ${ }^{\text {th }}$ Aug 2018; accepted $31^{\text {st }}$ Oct 2018)
}

\begin{abstract}
Effects of deep fertilizer placement on rice growth and yield were investigated with two rice cultivars Meixiangzhan2 and Xiangyaxiangzhan. Four treatments of pre-transplant tillage + fertilizer application were set: $(\mathrm{CK})$ twice puddling with rotary cultivator + manual surface broadcast; $(\mathrm{CD})$ twice puddling through rotary cultivator $+10-\mathrm{cm}$ deep mechanized placement; $(\mathrm{ZB})$ no pudding + manual surface broadcast; (ZD) no pudding $+10-\mathrm{cm}$ deep mechanized placement. Treatments CD and ZD both significantly improved the grain yield and panicle number unit area compared with treatments $C K$ and ZB. Dry accumulation, chlorophyll contents and net photosynthetic rate at both the heading stage and maturity stage were enhanced by the deep fertilizer placement. Thus, we think the benefits of mechanical deep fertilizer placement have potential to break the production limitation and popularization in conservation tillage.
\end{abstract}

Keywords: zero tillage, rice; deep placement of fertilizer, grain yield, photosynthesis, chlorophyll, dry matter accumulation

\section{Introduction}

As a crop feeding more than half of the global population, the major species of rice (Oryza sativa L.) is only grown and consumed in Asia (Abid et al., 2015). The rice production and food security become increasingly important since the world population is rising year by year (Miao et al., 2011). Many factors affect the productivity of rice plants, such as the amount and application method of fertilizer. As reported, nitrogen application at $180 \mathrm{~kg}\left(\mathrm{~N} \cdot \mathrm{ha}^{-1}\right)$ remarkably enhanced the net photosynthetic rate, yield, and total nitrogen and potassium accumulation (Pan et al., 2016). Nitrogen use at $60 \mathrm{~kg} \cdot \mathrm{hm}^{-2}$ at both the tillering stage and booting stage increased not only panicle number per hill and grain yield, but also the 2-acety-1-pyrroline (2-AP) contents of aromatic rice (Ren et al., 2017). Moreover, the silicon fertilizer also could improve net photosynthetic rates, 2-AP contents and rice yield (Mo et al., 2017).

Recently, the conversation tillage methods such as minimum tillage and zero tillage have increasingly attracted farmers and researchers because of the soil problems (e.g. poor soil structure) and the negative effect of tillage on soil organism. Compared with 
conventional tillage, rice under zero tillage accumulates more roots in the surface soil layer (Huang et al., 2018) and thus has more roots distributed in the soil fertilizer with high nitrogen content and less nitrogen fertilizer, which might be needed. However, zero- tillage rice takes long time to uptake the basal nitrogen, which induces the loss of nitrogen fertilizer (Cheng-Fang et al., 2011). Similarly, the nitrogen uptake in zerotillage rice was delayed at early growth stages, due to the inhibition of root growth caused by the rhizospheric accumulation of inhibitory pseudomonads (Huang et al., 2012). Even worse, because of the labor shortage and increasing labor costs, rice farmers usually applied fertilizers only once before crop establishment just to avoid in season fertilizer application (Peng et al., 2008). Hence, the fertilizer use efficiency of zero-tillage rice should be enhanced.

Appropriate time and amount of nitrogen application could improve the nitrogen use efficiency (Sun et al., 2015; Mohanty et al., 1998). However, the mechanical hill transplanted rice synchronized with deep fertilizer placement was able to puddle, transplant and apply fertilizer simultaneously combining a harrow and a furrower opener. Deep placement of nitrogen fertilizer improved the nitrogen use efficiency, spikelet number per panicle and grain yield (Pan et al., 2017). Moreover, deep fertilizer placement significantly increased the grain yields compared with broadcasting (Bandaogo et al., 2015), and thus might be the most efficient and promising method to prevent fertilizer loss.

The present study was conducted in Guangdong (a major rice-producing province in South China) in order to examine the effects of deep fertilizer placement on rice photosynthesis and yield.

\section{Materials and methods}

\section{Plant materials and growing conditions}

Two rice cultivars, Xiangyaxiangzhan and Meixiangzhan2 having a growth period of 111-114 days, were planted at early season of 2018 in Zengcheng $\left(23^{\circ} 13^{\prime} \mathrm{N}, 113^{\circ} 81^{\prime} \mathrm{E}\right.$, altitude $11 \mathrm{~m}$ ), Guangdong. The experimental site enjoyed a subtropical monsoon climate (Fig. 1). Before sowing, the seeds were soaked in water for $24 \mathrm{~h}$, germinated in manual climatic boxes for another $24 \mathrm{~h}$ and shade-dried. The germinated seeds were sown in polyvinyl chloride trays for nursery raising. Then 15 -day-old seedlings were transplanted to the field at the planting distance of $30 \times 12 \mathrm{~cm}^{2}$ on April 1, 2018 and harvested on July 16, 2018. The experimental soil in Zengcheng was sandy loam containing $20.12 \%$ organic matter, $1.408 \%$ total $\mathrm{N}, 1.068 \%$ total $\mathrm{P}$, and $15.767 \%$ total $\mathrm{K}$.

\section{Treatment and plant sampling}

The experiment was conducted in early season and the commercial compound fertilizer (YaraMila Fertilizer Company, China) was applied at the same amount of $105 \mathrm{~kg} \cdot \mathrm{N} \cdot \mathrm{ha}^{-1}$. Four treatments of pre-transplant tillage + fertilizer application were set up: $(\mathrm{CK})$ conventional manage practice, twice puddling with rotary cultivator + manual surface broadcast; $(C D)$ twice puddling with rotary cultivator $+10 \mathrm{~cm}$ deep mechanized placement; (ZB) no pudding + manual surface broadcast; (ZD) no pudding $+10 \mathrm{~cm}$ deep mechanized placement. Ten random rice plants from each plot were collected for estimation of dry matter accumulation in the tillering stage (TS), heading stage (HS) 
and maturity stage (MS), respectively. Fresh leaves were sampled from the rice at each stage and immediately stored at $-80{ }^{\circ} \mathrm{C}$ for determination of chlorophyll contents.

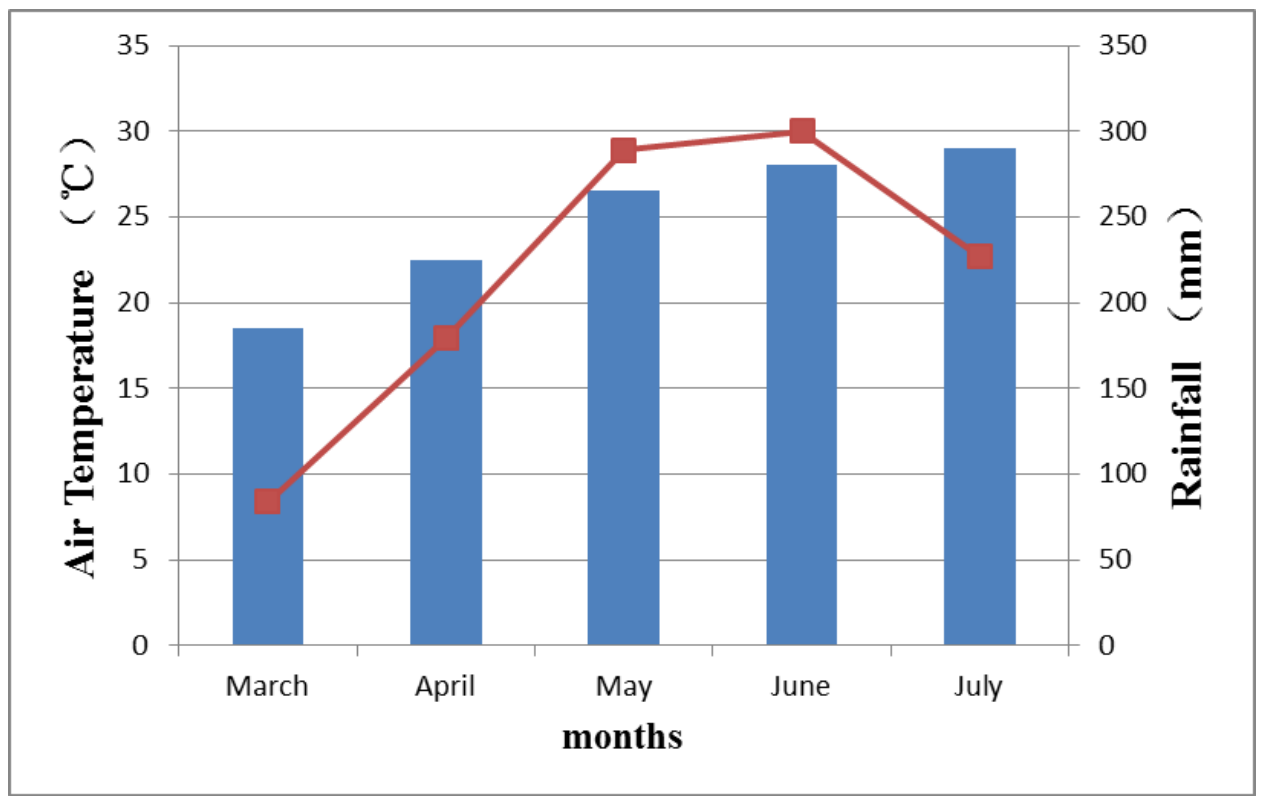

Figure 1. Mean monthly temperature and rainfall during the experiment site

\section{Photosynthesis}

Photosynthesis was measured at the three stages. Net photosynthetic rate and gas exchange attributes were measured using a portable photosynthesis system (LI-6400, LI-COR, USA) at 09:00-10:30 a.m. according to the standard method described by Kong et al. (2017).

\section{Detection of chlorophyll contents}

Typically, a ground leaf sample (about $0.1 \mathrm{~g}$ ) was placed in a $15 \mathrm{ml}$ centrifuge tube added with $95 \%$ absolute ethyl alcohol $(10 \mathrm{ml})$ and then kept in the dark until the sample turned white. Then contents of total chlorophyll (total Chl), chlorophyll a (Chl a) and chlorophyll $\mathrm{b}(\mathrm{Chl} \mathrm{b})$ were detected on a ultraviolet visible spectrophotometer at 645, 652 and $663 \mathrm{~nm}$, respectively according to Anjum et al. (2016).

\section{Yield and yield-related traits}

At the maturity stage, the rice grains were harvested from one unit sampling area $\left(25 \mathrm{~m}^{2}\right)$ in each plot and threshed by machine. Then after sun drying, the grain yield was determined on basis of the dry weight. Twenty five random hills of rice plants in each plot were sampled for calculating the average effective panicle number per hill. Then four hills of rice plants from each plot were taken to determine the yield- related traits.

\section{Treatment design and statistical analysis}

This study was managed as a randomized complete block design with four replicates $(n=4)$. Data were analyzed on Statistix 8.1 (Analytical Software, Tallahassee, FL, 
USA) at the probability level of $5 \%$ (P < 0.05). Differences among means were separated by using least significant difference (LSD) test.

\section{Results}

\section{Grain yield and yield-related traits}

The grain yield and related traits were all different to some extent under different tillage conditions and fertilizer applications (Table 1). The trend of yield was: $\mathrm{CD}=\mathrm{ZD}$ $>\mathrm{CK}=\mathrm{ZB}$, but no significant difference between $\mathrm{CD}$ and $\mathrm{ZD}$ was found for either Meixiangzhan2 or Xiangyaxiangzhan. The panicle number per unit area maximized in $\mathrm{CD}$ and minimized in ZB. Moreover, no remarkable difference among treatments was found in seed-setting rate or 1000-grain weight. Xiangyaxiangzhan had higher yield and seed-setting rate than Meixiangzhan-2.

Table 1. Effects of tillage and fertilizer application on grain yield and yield-related traits

\begin{tabular}{c|c|c|c|c|c|c}
\hline \multicolumn{1}{c}{ Cultivar } & Treatment & $\begin{array}{c}\text { Panicle } \\
\text { number per } \mathbf{~ m}^{\mathbf{2}}\end{array}$ & $\begin{array}{c}\text { Grains number } \\
\text { per panicle }\end{array}$ & $\begin{array}{c}\text { Seed-setting } \\
\text { rate } \mathbf{( \% )}\end{array}$ & $\begin{array}{c}\text { 1000-grain } \\
\text { weight }(\mathbf{g})\end{array}$ & $\begin{array}{c}\text { Yield } \\
\left(\mathbf{t ~ h m}^{-2}\right)\end{array}$ \\
\hline \multirow{3}{*}{ Meixiangzhan2 } & $\mathrm{CK}$ & $302.33 \pm 4.50 \mathrm{c}$ & $78.33 \pm 5.81 \mathrm{a}$ & $75.57 \pm 3.19 \mathrm{a}$ & $19.97 \pm 0.68 \mathrm{a}$ & $3.60 \pm 0.13 \mathrm{~b}$ \\
& $\mathrm{CD}$ & $350.00 \pm 6.49 \mathrm{a}$ & $82.56 \pm 2.85 \mathrm{a}$ & $80.50 \pm 3.08 \mathrm{a}$ & $21.13 \pm 0.86 \mathrm{a}$ & $4.08 \pm 0.18 \mathrm{a}$ \\
& $\mathrm{ZB}$ & $278.33 \pm 5.24 \mathrm{~d}$ & $74.67 \pm 4.63 \mathrm{a}$ & $81.13 \pm 1.08 \mathrm{a}$ & $19.87 \pm 0.76 \mathrm{a}$ & $3.51 \pm 0.13 \mathrm{~b}$ \\
& $\mathrm{ZD}$ & $339.67 \pm 7.22 \mathrm{~b}$ & $83.67 \pm 2.91 \mathrm{a}$ & $83.30 \pm 0.84 \mathrm{a}$ & $20.80 \pm 0.61 \mathrm{a}$ & $3.89 \pm 0.27 \mathrm{a}$ \\
\hline \multirow{3}{*}{ Xiangyaxiangzhan } & $\mathrm{CK}$ & $294.67 \pm 3.18 \mathrm{~b}$ & $87.33 \pm 6.36 \mathrm{a}$ & $78.50 \pm 2.37 \mathrm{a}$ & $20.53 \pm 0.70 \mathrm{a}$ & $4.15 \pm 0.12 \mathrm{~b}$ \\
& $\mathrm{CD}$ & $346.33 \pm 3.30 \mathrm{a}$ & $97.33 \pm 0.88 \mathrm{a}$ & $80.53 \pm 1.40 \mathrm{a}$ & $21.40 \pm 0.41 \mathrm{a}$ & $5.73 \pm 0.11 \mathrm{a}$ \\
& $\mathrm{ZB}$ & $272.00 \pm 8 \mathrm{~b}$ & $92.00 \pm 1.76 \mathrm{a}$ & $79.97 \pm 1.85 \mathrm{a}$ & $19.47 \pm 0.71 \mathrm{a}$ & $3.80 \pm 0.11 \mathrm{~b}$ \\
& $\mathrm{ZD}$ & $335.33 \pm 7.02 \mathrm{a}$ & $87.67 \pm 7.00 \mathrm{a}$ & $83.17 \pm 2.05 \mathrm{a}$ & $21.97 \pm 0.83 \mathrm{a}$ & $5.34 \pm 0.19 \mathrm{a}$ \\
\hline
\end{tabular}

Means in the same column followed by different lower case letters for the same variety differ significantly at $\mathrm{P}<0.05$ by T-test, the same as below

\section{Dry matter accumulation}

Significant differences were found among different tillage and fertilizer applications (Fig. 2). For Meixiangzhan2, the trends at the tillering, heading and maturity stages were the same: $\mathrm{CD}>\mathrm{ZD}>\mathrm{CK}=\mathrm{ZB}$, but no significant difference between $\mathrm{CK}$ and $\mathrm{ZB}$ was found. For Xiangyaxiangzhan, compared with CK, dry matters were 1.52, 1.21, 1.34, 1.22, 1.32 and 1.23 fold higher in $\mathrm{CD}$ and $\mathrm{ZD}$ at the tillering, heading and maturity stages, respectively. No significant difference in dry matter accumulation was found between $\mathrm{CD}$ and $\mathrm{ZD}$ at the heading stage. In addition, at heading stage and maturity stage, there was higher dry matter weight in Meixiangzhan-2 than Xiangyaxiangzhan.

\section{Chlorophyll contents}

The methods of fertilizer application significantly affected the chlorophyll contents (Table 2). For Meixiangzhan2, the trend of total Chl contents was: $\mathrm{CD}=\mathrm{ZD}>\mathrm{CK}=\mathrm{ZB}$ at each stage, while no significant difference between $\mathrm{CD}$ and $\mathrm{ZD}$ and similar trends were observed in the contents of $\mathrm{Chl}$ a and $\mathrm{Chl} \mathrm{b}$. For Xiangyaxiangzhan, the contents of total Chl, $\mathrm{Chl}$ a and $\mathrm{Chl} b$ also maximized in $\mathrm{CD}$, while the chlorophyll contents of 
ZD were all higher than both $\mathrm{CK}$ and ZB. Furthermore, the total chlorophyll and chlorophyll a content of Xiangyaxiangzhan at tillering stage and heading stage were higher than Meixiangzhan-2.

Dry matter accmulation (g plant ${ }^{-1}$ )
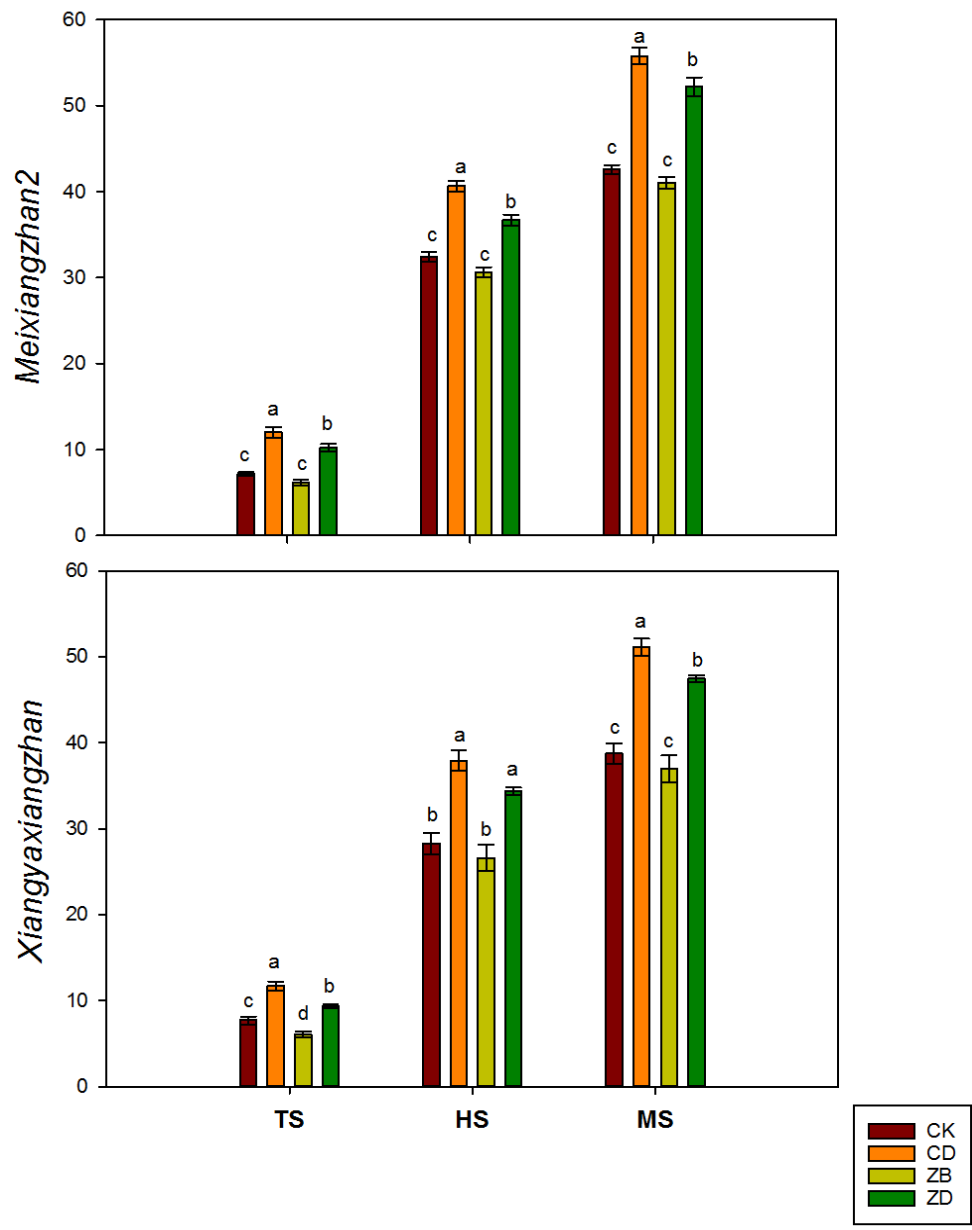

Figure 2. Effects of tillage and fertilizer application on dry matter accumulations (TS mean tillering stage, HS mean heading stage, MS mean maturity stage, the same as below)

Table 2. Effects of tillage and fertilizer application on chlorophyll contents

\begin{tabular}{|c|c|c|c|c|c|c|c|c|c|c|}
\hline \multirow{2}{*}{ Cultivar } & \multirow{2}{*}{ Treatment } & \multicolumn{3}{|c|}{ Total Chl $\left(\mathrm{mg} \cdot \mathrm{g}^{-1}\right)$} & \multicolumn{3}{|c|}{ Chl a (mg $\left.\cdot \mathrm{g}^{-1}\right)$} & \multicolumn{3}{|c|}{ Chl b (mg $\left.\cdot \mathbf{g}^{-1}\right)$} \\
\hline & & TS & HS & MS & TS & HS & MS & TS & HS & MS \\
\hline \multirow{4}{*}{ Meixiangzhan2 } & CK & $2.87 \pm 0.06 \mathrm{~b}$ & $2.46 \pm 0.06 \mathrm{~b}$ & $0.65 \pm 0.02 \mathrm{~b}$ & $1.94 \pm 0.04 \mathrm{~b}$ & $1.59 \pm 0.04 \mathrm{~b}$ & $0.40 \pm 0.01 \mathrm{~b}$ & $0.69 \pm 0.02 b$ & $0.57 \pm 0.01 \mathrm{~b}$ & $0.15 \pm 0.01 \mathrm{~b}$ \\
\hline & $\mathrm{CD}$ & $3.40 \pm 0.07 \mathrm{a}$ & $2.83 \pm 0.03 \mathrm{a}$ & $0.82 \pm 0.02 \mathrm{a}$ & $2.30 \pm 0.05 \mathrm{a}$ & $1.83 \pm 0.02 \mathrm{a}$ & $0.49 \pm 0.01 \mathrm{a}$ & $0.82 \pm 0.02 \mathrm{a}$ & $0.65 \pm 0.01 \mathrm{a}$ & $0.19 \pm 0.01 \mathrm{a}$ \\
\hline & $\mathrm{ZB}$ & $2.80 \pm 0.04 \mathrm{~b}$ & $2.42 \pm 0.06 \mathrm{~b}$ & $0.60 \pm 0.03 b$ & $1.89 \pm 0.03 \mathrm{~b}$ & $1.56 \pm 0.04 \mathrm{~b}$ & $0.36 \pm 0.02 b$ & $0.67 \pm 0.01 \mathrm{~b}$ & $0.56 \pm 0.01 \mathrm{~b}$ & $0.14 \pm 0.01 \mathrm{~b}$ \\
\hline & ZD & $3.22 \pm 0.06 \mathrm{a}$ & $2.76 \pm 0.03 \mathrm{a}$ & $0.77 \pm 0.0 \mathrm{a}$ & $2.17 \pm 0.04 \mathrm{a}$ & $1.79 \pm 0.02 \mathrm{a}$ & $0.46 \pm 0.01 \mathrm{a}$ & $0.78 \pm 0.02 \mathrm{a}$ & $0.64 \pm 0.01 \mathrm{a}$ & $0.17 \pm 0.01 \mathrm{a}$ \\
\hline \multirow{4}{*}{ Xiangyaxiangzhan } & $\mathrm{CK}$ & $3.14 \pm 0.03 \mathrm{~b}$ & $2.65 \pm 0.04 \mathrm{c}$ & $0.76 \pm 0.02 \mathrm{~b}$ & $2.14 \pm 0.02 \mathrm{~b}$ & $1.72 \pm 0.03 \mathrm{c}$ & $0.47 \pm 0.01 \mathrm{~b}$ & $0.77 \pm 0.01 \mathrm{~b}$ & $0.63 \pm 0.01 \mathrm{c}$ & $0.18 \pm 0.01 \mathrm{~b}$ \\
\hline & $\mathrm{CD}$ & $3.55 \pm 0.05 \mathrm{a}$ & $2.99 \pm 0.05 \mathrm{a}$ & $0.92 \pm 0.04 \mathrm{a}$ & $2.42 \pm 0.04 \mathrm{a}$ & $1.95 \pm 0.03 \mathrm{a}$ & $0.57 \pm 0.02 \mathrm{a}$ & $0.87 \pm 0.01 \mathrm{a}$ & $0.71 \pm 0.01 \mathrm{a}$ & $0.21 \pm 0.01 \mathrm{a}$ \\
\hline & $\mathrm{ZB}$ & $2.77 \pm 0.12 \mathrm{c}$ & $2.55 \pm 0.06 \mathrm{c}$ & $0.74 \pm 0.03 \mathrm{~b}$ & $1.88 \pm 0.08 \mathrm{c}$ & $1.66 \pm 0.04 \mathrm{c}$ & $0.46 \pm 0.02 b$ & $0.68 \pm 0.03 \mathrm{c}$ & $0.60 \pm 0.01 \mathrm{c}$ & $0.17 \pm 0.01 \mathrm{~b}$ \\
\hline & $\mathrm{ZD}$ & $3.45 \pm 0.12 \mathrm{a}$ & $2.85 \pm 0.04 \mathrm{~b}$ & $0.88 \pm 0.03 \mathrm{a}$ & $2.34 \pm 0.04 \mathrm{a}$ & $1.85 \pm 0.02 b$ & $0.54 \pm 0.02 \mathrm{a}$ & $0.84 \pm 0.02 \mathrm{a}$ & $0.67 \pm 0.01 \mathrm{~b}$ & $0.20 \pm 0.01 \mathrm{a}$ \\
\hline
\end{tabular}




\section{Photosynthesis}

The net photosynthetic rates were quite different among the four treatments (Fig. 3). At tillering stage, no remarkable difference among $\mathrm{CK}, \mathrm{CD}, \mathrm{ZB}$ and $\mathrm{ZD}$ was found for either Meixiangzhan2 or Xiangyaxiangzhan. However, at heading stage and maturity stage, the net photosynthetic rates in $\mathrm{CD}$ and $\mathrm{ZD}$ were significantly higher than $\mathrm{ZB}$ and $\mathrm{CK}$, and the trends were: $\mathrm{CD}=\mathrm{ZD}>\mathrm{CK}=\mathrm{ZB}$. At tillering stage, Meixiangzhan-2 had higher net photosynthetic rate than Xiangyaxiangzhan whilst at heading stage, net photosynthetic rate of Meixiangzhan-2 was lower than Xiangyaxiangzhan and at maturity stage, there was no significant difference between two rice cultivars.

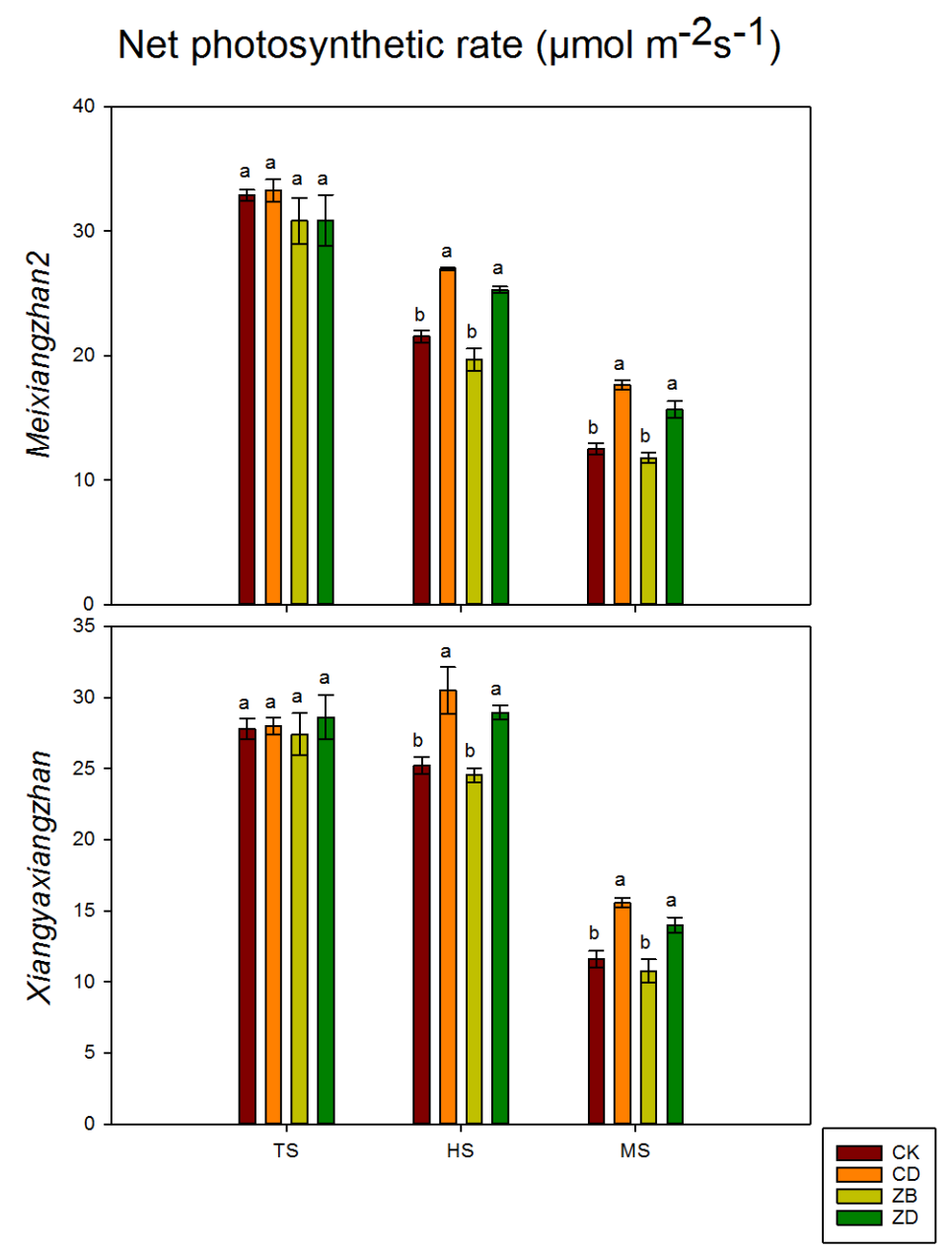

Figure 3. Effects of tillage and fertilizer application on net photosynthetic rate

\section{Correlation analysis}

As showed in Table 3, the rice yield was significantly and positively correlated with panicle number per $\mathrm{m}^{2}$, grain number per panicle, 1000-grain weight, dry matter at tillering stage, total Chl content, and net photosynthetic rate at heading stage. The 1000grain weight was also positively related with the net photosynthetic rate at heading stage. Furthermore, dry matter accumulation at maturity stage was significantly correlated with total $\mathrm{Chl}$ contents at all three stages as well as net photosynthetic rates at both heading stage and maturity stage. 
Table 3. Relationship among yield, yield related traits, dry matter accumulation, chlorophyll contents and net photosynthetic rate

\begin{tabular}{|c|c|c|c|c|c|c|c|c|c|c|c|c|c|c|}
\hline \multirow{2}{*}{\multicolumn{2}{|c|}{ Parameter }} & \multirow{2}{*}{$\begin{array}{c}\text { Panicle } \\
\text { number } \\
\text { per } \mathbf{m}^{2}\end{array}$} & \multirow{2}{*}{$\begin{array}{c}\text { Grains } \\
\text { number } \\
\text { per panicle }\end{array}$} & \multirow{2}{*}{$\begin{array}{l}\text { Seed- } \\
\text { setting } \\
\text { rate }\end{array}$} & \multirow{2}{*}{$\begin{array}{l}\text { 1000-grain } \\
\text { weight }\end{array}$} & \multicolumn{3}{|c|}{ Dry matter accumulation } & \multicolumn{3}{|c|}{ Total chl } & \multicolumn{3}{|c|}{ Net photosynthetic rate } \\
\hline & & & & & & $\mathrm{TS}$ & HS & MS & TS & HS & MS & TS & HS & MS \\
\hline \multicolumn{2}{|c|}{ Panicle number per $\mathrm{m}^{2}$} & & & & & & & & & & & & & \\
\hline \multicolumn{2}{|c|}{$\begin{array}{l}\text { Grains number per } \\
\text { panicle }\end{array}$} & -0.0033 & & & & & & & & & & & & \\
\hline \multicolumn{2}{|l|}{ Seed-setting rate } & 0.2365 & -0.1935 & & & & & & & & & & & \\
\hline \multicolumn{2}{|l|}{ 1000-grain weight } & $0.4136^{*}$ & -0.1422 & $0.4724 *$ & & & & & & & & & & \\
\hline \multirow{3}{*}{$\begin{array}{l}\text { Dry matter } \\
\text { accumulation }\end{array}$} & $\mathrm{TS}$ & $0.9150 * *$ & 0.001 & 0.2478 & $0.5331 * *$ & & & & & & & & & \\
\hline & HS & $0.8442 *$ & -0.2057 & 0.1386 & 0.3662 & $0.8448 * *$ & & & & & & & & \\
\hline & MS & $0.8692 * *$ & -0.2138 & 0.2479 & 0.4009 & $0.8744 * *$ & $0.9823 * *$ & & & & & & & \\
\hline \multirow{3}{*}{ Total Chl } & $\mathrm{TS}$ & $0.8118^{* *}$ & 0.1176 & 0.2275 & $0.5663 * *$ & $0.8337 * *$ & $0.7015^{* *}$ & $0.7261 * *$ & & & & & & \\
\hline & HS & $0.7888 * *$ & 0.1257 & 0.3132 & $0.5376^{* *}$ & $0.8186^{* *}$ & $0.6370 * *$ & $0.6810 * *$ & $0.8731 * *$ & & & & & \\
\hline & MS & $0.6991 * *$ & 0.3622 & 0.3111 & $0.5013^{*}$ & $0.7293 * *$ & $0.4815^{*}$ & $0.5158 * *$ & $0.7738 * *$ & $0.8835 * *$ & & & & \\
\hline \multirow{3}{*}{$\begin{array}{l}\text { Net photosynthetic } \\
\text { rate }\end{array}$} & $\mathrm{TS}$ & -0.1799 & -0.0576 & -0.0559 & -0.1039 & -0.0877 & 0.1026 & 0.1002 & -0.0899 & -0.1561 & -0.1503 & & & \\
\hline & HS & $0.7289 * *$ & 0.3622 & 0.3111 & $0.5013 *$ & $0.7293 * *$ & $0.4815^{*}$ & $0.5158 * *$ & $0.7738 * *$ & $0.8835 * *$ & $0.7653 * *$ & -0.1503 & & \\
\hline & MS & $0.8704 * *$ & -0.155 & 0.2587 & $0.4512 *$ & $0.8836^{* *}$ & $0.8766 * *$ & $0.9045^{* *}$ & $0.7523 * *$ & $0.6763 * *$ & $0.5528 * *$ & 0.0431 & 0.5528 & \\
\hline \multicolumn{2}{|l|}{ Yield } & $0.5759 * *$ & $0.5444 * *$ & 0.1996 & $0.5227 * *$ & $0.5467 * *$ & 0.3287 & 0.3176 & $0.6916^{* *}$ & $0.7090 * *$ & $0.7661 * *$ & -0.0333 & $0.7661 * *$ & 0.3634 \\
\hline
\end{tabular}




\section{Discussion}

Normally, puddling not only is a helpful method to prevent the loss of water and nutrients, but also decreases the weeds and volunteer rice in rice production (Sharma et al., 2018). In China, the conventional tillage (by moldboard plowing and rotavating) is the most widely used for paddy field preparation (Huang et al., 2011). However, this practice requires abundant energy and labor, accelerates organic mineralization, reduces soil fertility, increases water consumption, and even damages the physiochemical properties of soils (Chen Song et al., 2007; Bhushan et al., 2007). Thus, zero tillage has become increasingly attractive in these years because of the benefits of saving fuel, equipment, and labor as well as conserving soil (Huang et al., 2011). However, without the advantages which are only provided by puddling, the growth of zero tillage rice might not be good as much as that in conventional tillage. Our study evidences this consideration by showing that the rice yield under ZB condition is lower than CK for both Meixiangzhan2 and Xiangyaxiangzhan, though not significantly. At tillering stage, the total $\mathrm{Chl}, \mathrm{Chl}$ a and $\mathrm{Chl} \mathrm{b}$ contents and plant dry weight in ZB were remarkably lower than in CK for Xiangyaxiangzhan, indicating the paddy field without puddling preparation might inhibit the early growth of rice.

Studies suggest that deep fertilizer placement is the most efficient and promising method to inhibit the fertilizer loss while improving the fertilizer use efficiency in rice production (Liu et al., 2015; Savant et al., 1990). Huda et al. (2016) revealed placement of urea briquettes significantly increased rice grain yield and nitrogen recovery efficiency compared with broadcast prilled briquettes across seasons and different water regimes. The present study showed deep placement of compound fertilizer significantly increased the grain yield. The yield and panicle number per $\mathrm{m}^{2}$ under ZD treatment were both significantly higher than either $\mathrm{CK}$ or $\mathrm{ZB}$ for two cultivars. Even no significant difference between $\mathrm{ZD}$ and $\mathrm{CD}$ was found in yield and its related traits. Our results agreed with Pan et al. (2017) who found mechanical deep placement of compound fertilizer significantly improved the grain yield of hill direct-seeded rice because of the larger grain number per panicle and seed-setting rate and that the photosynthetic rate at heading stage was improved by the deep fertilizer placement. Moreover, in addition to the heading stage, the net photosynthetic rate at maturity stage was also increased by deep fertilizer placement, while no significant difference among different treatments was found at tillering stage in our research. These results indicate the deep fertilizer placement could improve the rice growth at middle and later stages, which was mainly because it reduced the nutrition loss. For example, deep placement of nitrogen fertilizer induced the reduction of $\mathrm{NH}_{4}{ }^{+}-\mathrm{N}$ concentrations in the soils while applying floodwater from hydrolyzed nitrogen fertilizers because of lower soil urease activities than surface broadcasting (Liu et al., 2015). Hence, mechanical deep placement of fertilizer could be an efficient method to break the limitations on the production and popularization of conversation tillage.

\section{Conclusions}

Deep placement of commercial compound fertilizer enhanced the rice growth under zero tillage in terms of chlorophyll contents, dry matter accumulation and net photosynthetic rate. Deep fertilizer placement also improved the grain yield and panicle 
number per unit area in zero tillage. Continuing advancements in such emerging technology will be very helpful to the production and popularization in conversation tillage.

Acknowledgements. This study was supported by National Natural Science Foundation of China (31271646), National Key R\&D Program of China (2016YFD0700301), the World Bank Loan Agricultural Pollution Control Project in Guangdong (0724-1510A08N3684), the Technology System of Modern Agricultural Industry in Guangdong (2017LM1098) and Student's Platform for Innovation and Entrepreneurship Training Program (201810564029). The authors declare no conflicts of interest.

\section{REFERENCES}

[1] Abid, M., Khan, I., Mahmood, F., Ashraf, U., Imran, M., Anjum, S. A. (2015): Response of Hybrid Rice to Various Transplanting Dates and Nitrogen Application Rates. Philippine Agriculturist 98: 98-104.

[2] Anjum, S. A, (2016): Chromium toxicity induced alterations in growth, photosynthesis, gas exchange attributes and yield formation in maize. - Pakistan Journal of Agricultural Sciences 53: 751-757.

[3] Bandaogo, A., Bidjokazo, F., Youl, S., Safo, E., Abaidoo, R., Andrews, O. (2015): Effect of fertilizer deep placement with urea supergranule on nitrogen use efficiency of irrigated rice in Sourou Valley (Burkina Faso). - Nutrient Cycling in Agroecosystems 102: 79-89.

[4] Bhushan, L., Ladha, J. K., Gupta, R. K., Singh, S., Tirolpadre, A., Saharawat, Y. S., Gathala, M., Pathak, H. (2007): Saving of water and labor in a rice-wheat system with no-tillage and direct seeding technologies. - Agronomy Journal 99: 1288-1296.

[5] Cheng-Fang, L. I., Kou, Z. K., Zhang, Z. S., Cao, C. G., Hai-Ya, W. U., Mei, J. A., Zhai, Z. B., Zhang, C. D., Wei, T. X., Liu, S. Q. (2011): Effects of rape residue mulch on greenhouse gas emissions and carbon sequestration from no-tillage rice fields. - Journal of Agro-Environment Science.

[6] Chen, S., Xia, G.-M., Zhao, W.-M., Wu, F.-B., Zhang, G.-P. (2007): Characterization of leaf photosynthetic properties for no-tillage rice. - Rice Science (English Version) 14: 283-288.

[7] Huang, M., Ibrahim, M. D., Xia, B., Zou, Y. (2011a): Significance, progress and prospects for research in simplified cultivation technologies for rice in China. - Journal of Agricultural Science 149: 487-496.

[8] Huang, M., Zou, Y., Feng, Y., Cheng, Z., Mo, Y., Ibrahim, M., Xia, B., Jiang, P. (2011b): No-tillage and direct seeding for super hybrid rice production in rice-oilseed rape cropping system. - European Journal of Agronomy 34: 278-286.

[9] Huang, M., Zou, Y., Jiang, P., Xia, B., Feng, Y., Cheng, Z., Mo, Y. (2012): Effect of tillage on soil and crop properties of wet-seeded flooded rice. - Field Crops Research 129: 28-38.

[10] Huang, M., Zhou, X., Zou, Y. (2018): Improving nitrogen management for zero-tillage rice in China. - Crop Journal 6(4): 406-412.

[11] Huda, A., Gaihre, Y. K., Islam, M. R., Singh, U., Islam, M. R., Sanabria, J., Satter, M. A., Afroz, H., Halder, A., Jahiruddin, M. (2016): Floodwater ammonium, nitrogen use efficiency and rice yields with fertilizer deep placement and alternate wetting and drying under triple rice cropping systems. - Nutrient Cycling in Agroecosystems 104: 53-66.

[12] Kong, L., Ashraf, U., Cheng, S., Rao, G., Mo, Z., Tian, H., Pan, S., Tang, X. (2017): Short-term water management at early filling stage improves early-season rice performance under high temperature stress in South China. - European Journal of Agronomy 90: 117-126. 
[13] Liu, T. Q., Fan, D. J., Zhang, X. X., Chen, J., Li, C. F., Cao, C. G. (2015a): Deep placement of nitrogen fertilizers reduces ammonia volatilization and increases nitrogen utilization efficiency in no-tillage paddy fields in central China. - Field Crops Research 184: 80-90.

[14] Miao, Y., Zhang, F. (2011): Long-term experiments for sustainable nutrient management in China. A review. - Agronomy for Sustainable Development 31: 397-414.

[15] Mo, Z., Lei, S., Ashraf, U., Khan, I., Li, Y., Pan, S., Duan, M., Tian, H., Tang, X. (2017): Silicon fertilization modulates 2-acetyl-1-pyrroline content, yield formation and grain quality of aromatic rice. - Journal of Cereal Science 75: 17-24.

[16] Mohanty, S. K., Singh, U., Balasubramanian, V., Jha, K. P. (1998): Nitrogen deepplacement technologies for productivity, profitability, and environmental quality of rainfed lowland rice systems. - Nutrient Cycling in Agroecosystems 53: 43-57.

[17] Pan, S., Liu, H., Mo, Z., Patterson, B., Duan, M., Tian, H., Hu, S., Tang, X. (2016): Effects of Nitrogen and Shading on Root Morphologies, Nutrient accumulation, and photosynthetic parameters in different rice genotypes. - Scientific Reports 6: 32148.

[18] Peng, S., Tang, Q., Zou, Y. (2008): Current status and challenges of rice production in China. - Plant Production Science 12: 3-8.

[19] Ren, Y., (2017): Irrigation and nitrogen management practices affect grain yield and 2acetyl-1-pyrroline content in aromatic rice. - Applied Ecology and Environmental Research 15: 1447-1460.

[20] Savant, N. K., Stangel, P. J. (1990): Deep placement of urea supergranules in transplanted rice: principles and practices. - Fertilizer Research 25: 1-83.

[21] Sharma, P. C., Datta, A., Yadav, A. K., Choudhary, M., Jat, H. S., McDonald, A. (2018): Effect of crop management practices on crop growth, productivity and profitability of rice-wheat system in Western Indo-Gangetic Plains. - Proceedings of the National Academy of Sciences, India Section B: Biological Sciences. DOI: 10.1007/s40011-0180985-x.

[22] Sun, H., Zhang, H., Powlson, D., Min, J., Shi, W. (2015): Rice production, nitrous oxide emission and ammonia volatilization as impacted by the nitrification inhibitor 2-chloro-6(trichloromethyl)-pyridine. - Field Crops Research 173: 1-7. 